\title{
The Role of Wetland Plants on Wastewater Treatment and Electricity Generation in Constructed Wetland Coupled with Microbial Fuel Cell
}

\author{
$\mathrm{Ke} \mathrm{Li}^{1,2,3}$, Jingyao Qi ${ }^{2}$ *, Fuguo Zhang ${ }^{3}$, Nicholas Miwornunyuie ${ }^{4} \mathbb{D}$, Paulette Serwaa Amaniampong ${ }^{4}$, \\ Desmond Ato Koomson ${ }^{4}$, Lei Chen ${ }^{1}$, Yu Yan ${ }^{3}$, Yanhong Dong ${ }^{3}$, Victor Edem Setordjie ${ }^{4}$ \\ and Abigail Mwin-nea Samwini ${ }^{4}$
}

1 Key Laboratory of Song Liao Aquatic Environment, Ministry of Education, Jilin Jianzhu University, Changchun 130118, China; like123@163.com (K.L.); chenlei.jliae@hotmail.com (L.C.)

2 School of Environment, Harbin Institute of Technology, Harbin 150090, China

3 China Northeast Municipal Engineering Design and Research Institute Co. Ltd., Changchun 130021, China; Zhangfuguo2020@outlook.com (F.Z.); yanyu6699@outlook.com (Y.Y.); Dongyanhong725@163.com (Y.D.)

4 Key Laboratory of Integrated Regulation and Resource Development on Shallow Lake of Ministry of Education, College of Environment, Hohai University, No.1 Xikang Road, Nanjing 210098, China; nickchristos7@gmail.com (N.M.); pauletteserwaa@gmail.com (P.S.A.); m2018165@hhu.edu.cn (D.A.K.); nick.christos@hhu.edu.cn (V.E.S.); m20191314@hhu.edu.cn (A.M.-n.S.)

* Correspondence: jyq@hit.edu.cn

\section{check for}

updates

Citation: Li, K.; Qi, J.; Zhang, F.; Miwornunyuie, N.; Amaniampong, P.S.; Koomson, D.A.; Chen, L.; Yan, Y.; Dong, Y.; Setordjie, V.E.; et al. The Role of Wetland Plants on Wastewater Treatment and Electricity Generation in Constructed Wetland Coupled with Microbial Fuel Cell. Appl. Sci. 2021, 11, 7454. https://doi.org/ 10.3390/app11167454

Academic Editor: Marco Beccali

Received: 18 July 2021

Accepted: 8 August 2021

Published: 13 August 2021

Publisher's Note: MDPI stays neutral with regard to jurisdictional claims in published maps and institutional affiliations.

Copyright: (c) 2021 by the authors. Licensee MDPI, Basel, Switzerland. This article is an open access article distributed under the terms and conditions of the Creative Commons Attribution (CC BY) license (https:/ / creativecommons.org/licenses/by/ $4.0 /)$.

\begin{abstract}
CWMFC is a novel technology that has been used for almost a decade for concurrent wastewater treatment and electricity generation in varying scopes of domestic, municipal, and industrial applications since its implementation in 2012. Its advantage of low-cost enhanced wastewater treatment and sustainable bioelectricity generation has gained considerable attention. Nevertheless, the overall efficiency of this novel technology is inclined by several operating factors and configuration strands, such as $\mathrm{pH}$, sewage composition, organic loading, electrode material, filter media, electrogens, hydraulic retention time, and macrophytes. Here, we investigate the effect of the wetland plant component on the overall performance of CWMFCs. The macrophyte's involvement in the oxygen input, nutrient uptake, and direct degradation of pollutants for the required treatment effect and bioelectricity production are discussed in more detail. The review identifies and compares planted and unplanted CWMFC with their efficiency on COD removal and electricity generation based on previous and recent studies.
\end{abstract}

Keywords: electricity generation; wetland plants; wastewater treatment; microbial fuel cell; constructed wetlands

\section{Introduction}

Over the decades, many wastewater treatment technologies have been employed to address the wastewater environmental menace. Wastewater treatment technologies, which consist of trickling filters, activated sludge, reverse osmosis, and membrane filters, are currently being used to treat all types of organic and toxic wastewater from industrial and municipal sources. However, they are not very productive, with regards to the cost and energy demand required in their operation [1]. It is projected that USD 2 trillion will be required in the U.S.A over the next 20 years to construct, operate, and maintain wastewater and drinking water facilities [2]. In addition to the current annual costs of USD 25 billion, around USD 45 billion is expected for wastewater infrastructure upgrades, with over half of operating expenditures aimed at aeration of wastewater. Power production measured here only for aeration could provide much-needed energy in the U.S.A from industrial wastewater alone [3]. According to Gude (2015), some of these conventional wastewater treatment systems require $0.3-0.6 \mathrm{~kW} \cdot \mathrm{h} \cdot \mathrm{m}^{-3}$ for treatment, whereas inherent in the same 
wastewater is energy that is equivalent to 10 times that needed for treatment [4]. Hence, the concept of generating electrical energy from the inherent chemical energy (organic matter) in wastewater during the treatment process will help offset the financial burden of treatment and provide access to clean water throughout the world, which would be highly recognized as sustainable $[5,6]$.

In 1911, Michael C. Potter experimented and put forward the first microbial electrochemical technology (MET) and bio-electrochemical system (BES), established as microbial fuel cells (MFC), as a sustainable biotechnology [7,8]. A microbial fuel cell is an innovative wastewater treatment technology that uses electrochemical active bacteria (EAB) as a biocatalyst to transform the chemical energy inherent in sewage directly into electrical production without any environmental footprint [1,8]. MFCs use wastewater as a feed substrate for EABs to produce bio-electricity, while concurrently treating waste [1]. According to, Singh et al. [1], MFC as a technology holds great potential for a clean and green energy environment.

Constructed wetlands (CWs), on the other hand, are bio-physically assembled systems designed and built to take advantage of natural processes and interactions between wetland flora, soils, and associated microbial species to help regenerate wastewater $[9,10]$. Wastewater from a wide variety of sources, such as municipal, agricultural, or industrial wastewater, are treated by CWs [11]. They are easy to maintain and operate and can remediate many of the persistent pollutants that occur in conventional wastewaters into harmless by-products [12]. As a result, they have emerged as a substitute to traditional intensified systems for wastewater treatment $[13,14]$. A decade ago, researchers discovered that the embedded redox gradients, which naturally exist in wetlands, are highly compatible with the settings in microbial fuel cells, i.e., anaerobic zone in the inner-lower region and aerobic region at the air-water interface [15]. This connection makes their incorporation very plausible by creating a synergy between these two technologies for enhanced wastewater regeneration and bioenergy generation [16].

In the operation and utilization of this newly emerged technology, several factors are recognized to influence the system's efficiency, such as the appropriate selection of substrate media, microbial or electrogenic activities, hydraulic retention time, electrode material, and wetland plant type. Constructed wetland-microbial fuel cells (CWMFCs) for wastewater treatment and bioenergy generation can be categorized into free-floating, floating leave, rooted emergent, and submerged macrophyte systems, according to the dominant plant species [17]. Because of their tremendous contribution to the functioning of the system, the CWMFC or plant-microbial fuel cell (P-MFC) with installed macrophytes has stimulated considerable attention in the scientific community [18]. Over the decade, numerous aquatic plant species, such as Canna indica, Typha latifolia, Typha angustifolia, Phragmites australis, Ipomea aquatica, Elodea nuttallii, Glyceria maxima, Typha orientalis, Iris pseudacorus, Juncus effuses Cyperus prolifer, Wachendorfia thyrsiflora, etc. have been used in CWMFC (see Table 1) [19]. However, there is no detailed documentation of their involvement in the input of oxygen, uptake of nutrients, and the direct degradation of pollutants for the required treatment effect and electricity generation. This paper specifically explores the role of the wetland plant component in constructed wetlands integrated with microbial fuel cell systems and its influence on the generation of power and treatment of wastewater. Earlier and recent reviews on CWMFC by Srivastava et al. [20] concentrated on the electron's contribution to an electroactive wetland. Jingyu et al. [21] also focused on assessing the component factors that influence the efficiency of CW-MFC. Other reviews, as documented by Doherty et al. [22], Shi et al. [23], and Srivastava et al. [24], addressed dissimilar features of the technology. Doherty et al. [22] reviewed the efficiency of CW-MFCs as CW for effluent regeneration and CWMFCs as a microbial fuel cell for bioelectricity production. Srivastava et al. [24] also discussed the development and potential application of the technology. However, a detailed account of the physical, chemical, biological, and electrical contributions of the macrophyte component is not well documented, regarding CWMFC. This review summarizes the role of macrophytes in the regeneration of wastewater and 
their subsequent effects on CW-MFC bioenergy production. This study will help investigate the potential of the technology with or without the use of wetland plants and guide future research in selecting appropriate wetland plants.

\section{Configuration of CWMFC}

CWMFC is a hybrid system that seeks to integrate MFCs into built wetlands by leveraging the triple interaction of substrates, the plant and microorganisms' physical, chemical, and biotic elements for wastewater treatment and electricity production [25-27]. This hybrid system syndicates the advantage of two systems in a way that is proficient in attaining high levels of wastewater reuse and bioenergy [26]. On the basis of researchers identifying a variation of dissolved oxygen (DO) along the vertical profile of CW's natural environment, this integration was conceived to be plausible, which creates a naturally prevailing stratified redox gradient similar to that of MFC in its two-chambered cell, as shown in Figure 1 [16,28,29].
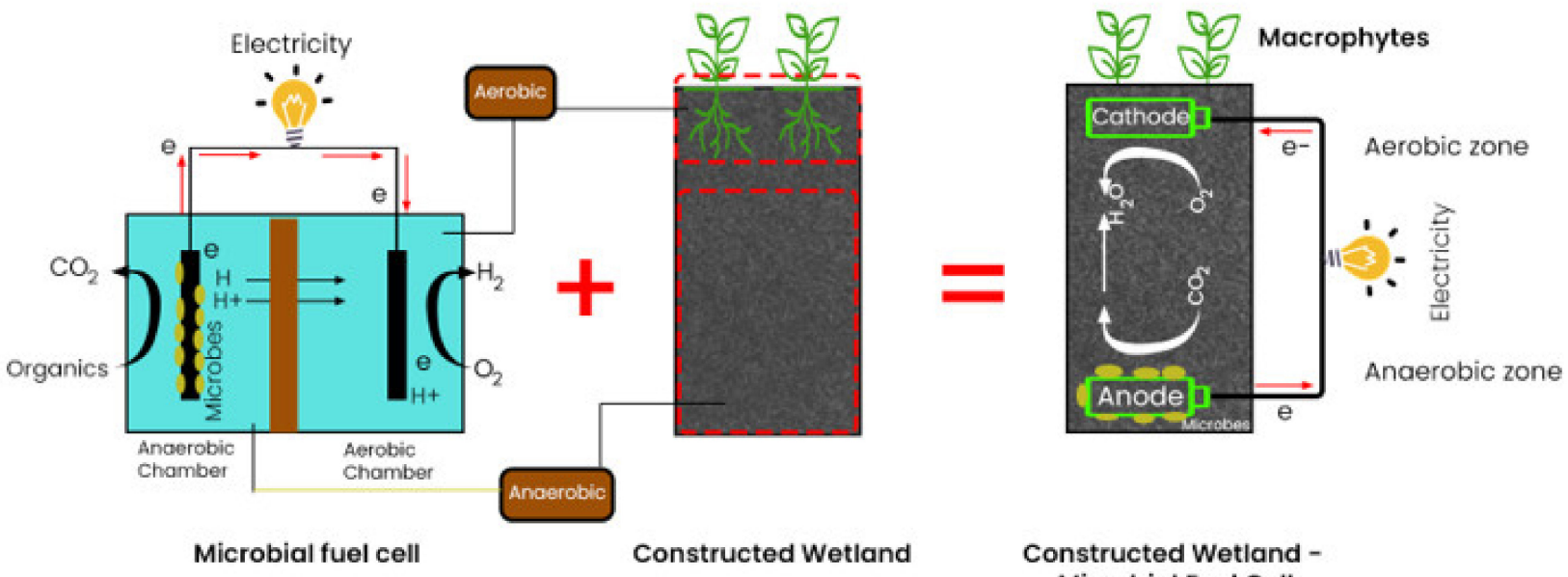

Figure 1. A graphical illustration of constructed wetland coupled MFC.

A typical CWMFC is, therefore, built similar to a traditional MFC with two major compartments-the lower anaerobic chamber and the upper aerobic chamber [27-31]with an anode electrode deeply buried within the anaerobic chamber and cathode electrode positioned at the air-water interface around the root zone of the plant, also called the aerobic or cathodic section [23]. These electrodes are then connected using titanium wires with an applied external resistance crucial for electricity generation. By positioning the anode at the lower anaerobic zone and inserting the cathode at the air-water interface, CW-MFC takes good advantage of the existing redox condition [31]. The optimization of this redox gradient or potential difference established betwixt the anode and the cathode is pivotal for power generation and contaminant removal in CWMFC [32]. Since the onset of this hybrid technology, carbon, and graphite materials have been widely used as electrodes, owing to their suitable surface microbial attachment and growth, high electrical conductivity, non-oxidative nature, and riveting characteristics for biofilm formation [14,33].

A CWMFC reactor configuration comparable to a built wetland often has its lower anaerobic region filled with a layer of soil, gravel or some other recent substrates, such as activated carbon, zeolite, or alum sludge, as a supporting matrix for the anode electrode. This support matrix also creates the desired environment for the oxidation reaction by microorganisms for contaminant removal and electrons transfer processes [14,16,26,33]. All these components, as mentioned earlier, are essential in the configuration of CW-MFC bioelectrochemical systems. However, to maintain a highly aerobic upper cathodic chamber and increase the removal of pollutants, macrophytes that resource dissolved oxygen to the cathode through plant root respiration are planted in the upper cathode compartment, which contributes significantly to the reduction reaction. Aside from the maintenance 
of appropriate operating conditions, such as $\mathrm{pH}$, temperature, organic loading rate flow regime, and hydraulic retention rate, the system's physical and biological components' performance is essential for the overall system efficiency [21]. The macrophyte components are recognized to play a pivotal role, as they interact with and influence the performance of all other required components, such as the substrate (filtration media), microorganisms, and electrode materials in CWMFC (see Figure 2). They also influence both the oxidation and reduction reactions. They act as biological filters and accumulators in the treatment process and as oxygenators to the cathode for electricity generation [15]. According to Fang et al. [34], the plants' presence promotes the cathode's oxygen concentration through their photosynthetic activities. In a study by Fang et al. [34], a CWMFC with plants produced an average voltage output of about 15\% higher than an unplanted CW-MFC [35-38].

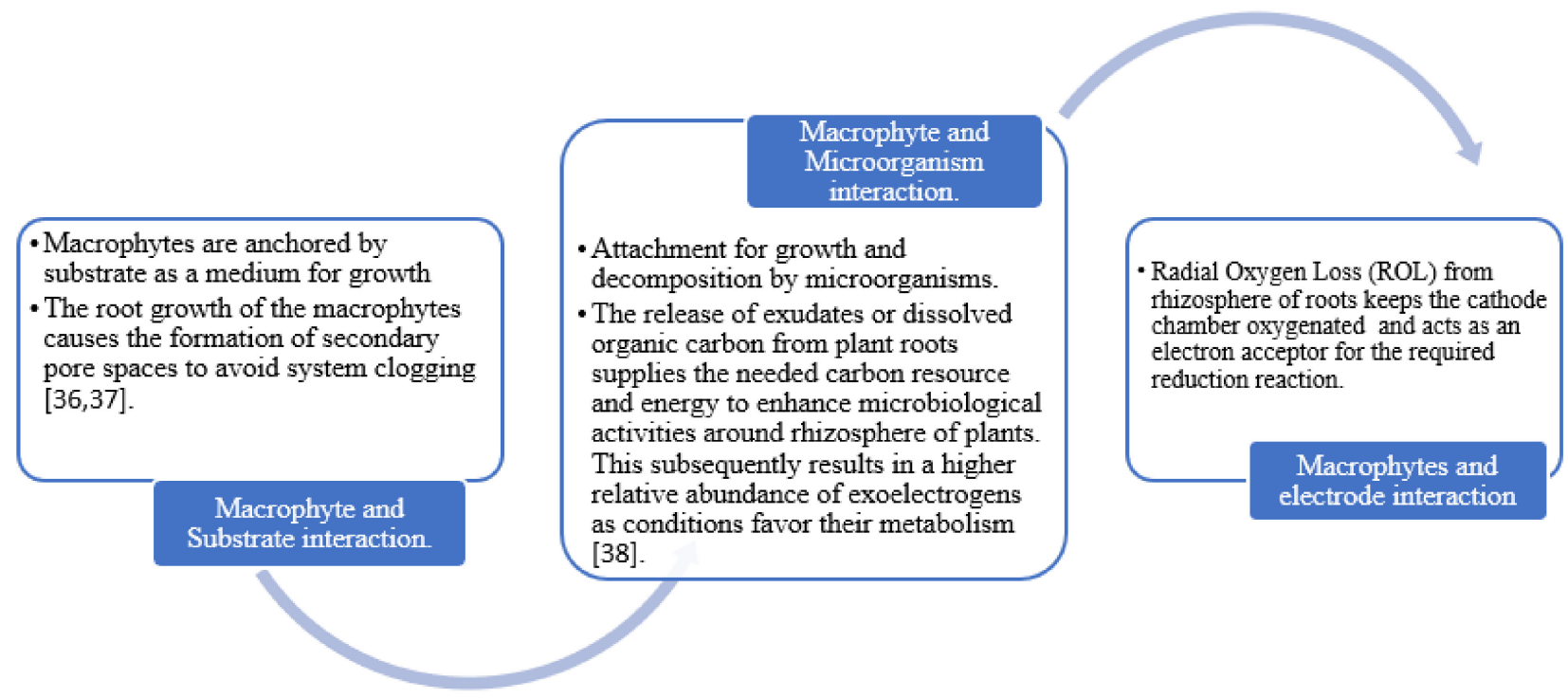

Figure 2. Interaction between macrophytes and other physical components of CWMFC.

\section{The Effect of Aquatic Macrophytes on Microbial Organisms}

Electroactive bacteria (EAB), or exoelectrogens, are generally recognized as the group of microorganisms that feature an essential role in the performance of CWMFCs. These are bacteria capable of generating electrical energy by organic matter oxidation and moving the electrons produced to an acceptor outside their cells $[14,16,38]$. In CW-MFC, the presence of macrophytes generally plays a crucial role in enhancing the abundance and diversity of the microbial community in CWMFC and their subsequent effect on contaminant removal and bioelectricity generation [15,37]. Their roots provide a vast surface area for microbial growth and attachment, allowing for the decomposition and uptake of pollutants from wastewater [39]. The efficiency of the system is primarily achieved by sustaining a high redox potential between the upper and lower segments of the CW-MFC. The involvement of aquatic macrophytes is one of the major components known to contribute to root oxygen and exudate secretion. Root oxygen released via plant root respiration, also known as radial oxygen loss (ROL), creates aerobic, anaerobic, and facultative aerobic conditions for various types of microorganisms. These conditions enhance the degradation of organic pollutants by facilitating microbial metabolism [40-44]. In addition, exudates consisting of carbohydrates, amino acids, and water-soluble sugar released by macrophyte roots provide the required carbon source and energy for the microbial metabolism and growth around the rhizosphere of the aquatic macrophyte. This, however, results in a greater relative abundance of EABs, which are responsible for bioelectricity production [37,41,42]. A recent study was undertaken by Wang et al. [45] to assess the influence of aquatic macrophytes on bioelectricity production, contaminant degradation, and micro bacterial community diversity in CWMFCs. The relative abundance of EABs (firmicutes and beta-proteobacteria) in 
planted CW-MFCs was substantially greater than that of unplanted CW-MFCs, according to the 16S rRNA microbial analysis of their study. These findings indicate that CWMFC with aquatic plants had a significant effect on the exoelectrogens' quantity around the anode material. Subsequently, the higher relative abundance of EABs in the planted CWMFC led to an increase in bioelectricity production of $8.91 \mathrm{~mW} \cdot \mathrm{m}^{-2}$ in CWMFC. On the other hand, the highest removal efficiency for $\mathrm{COD}$ and nitrate-nitrogen $\left(\mathrm{NO}_{3}-\mathrm{N}\right)$ was obtained in photosynthetic CW-MFC with smaller filler sizes of $86.7 \%$, and $87.1 \%$, respectively, which was strongly attributed to the diversity and relative abundance of microorganisms [45]. Similar to this study, Liu et al. [40] performed high-throughput sequencing in their experimentation to assess the effect of different macrophytes and no-macrophyte CWMFC; Canna indica, Acorus calamus, and Ipomoea aquatica on microbial diversity. According to the Shannon diversity indexes $\left(\mathrm{H}^{\prime}\right)$ of their study, species richness and evenness were relatively higher in planted than unplanted: $\mathrm{H}^{\prime}=4.69$. 4.94, 4.99, AND 5.01, respectively, for unplanted, Canna indica, Acorus calamus, and Ipomoea aquatica. More specifically, from the phylogenetic diversity of bacteria, the relative abundances of Geobacter (proteobacteria), the most well-known EAB in the anodes of the unplanted, Canna indica, Acorus calamus, and Ipomoea aquatica systems, were $5.12 \%, 20.41 \%, 11.67 \%$, and $20.74 \%$, respectively. This result was noticed to have greatly influenced a higher electrical output and the removal efficiency in CWMFC planted with Canna indica and Ipomoea aquatica than those that were unplanted due to microbial diversity as a result of the plant root exudate and oxygen release. In earlier studies by Shen et al. [44], to investigate the enhanced performance of CWMFC by using wetland plants and enclosed anodes, similar to Liu et al. [40], they used a fluorescence in situ hybridization (FISH) technique to estimate the abundance of Geobacter sulfurreducens and Betaproteobacteria in the anode biofilm; they obtained a positive correlation between the cell voltage and abundance of Geobacter sulfurreducens and Betaproteobacteria, which was $66.22 \%$ higher than the unplanted. In 2017, Wang et al. [46] also conducted a similar study to look at the relation between bioenergy generation and rhizodeposition and degradation in CWMFC. Their high-throughput sequencing similarly observed a wide variety of microbes (Clostridium sp., Cytophagales, and Dechloromonas sp., and so forth) in rhizosphere with a higher relative abundance of Desulfobulbus sp. and Geobacter sp. This result was well reflected in the bioenergy production in the planted system with T. orientalis and S. Validus as compared to the unplanted. According to Vymazal [47], the macrophytes' rhizosphere is known to accommodate a wide variety of bacterial forms that make planted CWMFCs outperform those that are unplanted [35,46,48].

\section{The Role of Macrophyte in Bioelectricity Generation}

The production of electricity in CWMFC is essentially the result of oxidation-reduction (redox) reactions through electrochemical or biochemical reactions at the anode and cathode chambers, respectively, as shown in Figure $3[18,21]$. The cathode electrode in the cathodic chamber features as an electron donor, whereas the anode fundamentally aids as an electron acceptor [49]. The acceptance of electrons from the cathode electrode for the reduction reaction in the cathode chamber is the responsibility of certain chemical compounds known as terminal electron acceptors (TEA). Transitional metals (e.g., platinum (Pt)) and nitrate $\left(\mathrm{NO}_{3}\right)$ compounds are materials often used as TEAs [50,51]. Nevertheless, oxygen $\left(\mathrm{O}_{2}\right)$ is generally recommended due to its sustainable characteristic and relatively high redox potential [51,52], for example, organic matter degradation using glucose as the substrate and oxygen as the electron acceptor.

Therefore, using DO at the system's air-water interface is considered ideal to make oxygen available for this reaction. Given that, some researchers employed air-cathodes to increase the cathodic reduction reaction by engaging the cathode material at the air-water interface. However, this arrangement was affected by huge ohmic losses because such an arrangement widens the distance between electrodes (the anode and the cathode), which increases the internal resistance of the cell $[22,23]$. In addition to the air-cathode that suffered setbacks of increased internal resistance, some other researchers also employed supplemen- 
tary artificial aeration. According to Guo et al. [53], the supplemental artificial aeration was recognized as a form of energy wastage and inhibited the denitrification process. The use of macrophytes to meet this major requirement became a huge breakthrough for the optimal functioning of the system. The prerequisite for oxygen without any setbacks in the upper cathodic region for the mentioned reduction reaction makes the macrophyte component a significant part of the system to guarantee optimum performance and efficiency [14]. The macrophyte plants use sunlight as an energy source during photosynthesis to turn water and carbon dioxide into chemical energy (glucose), and the by-product is gaseous $\mathrm{O}_{2}$ in their rhizosphere, which is then made available as TEAs to complete the energy production cycle in the system [54] as shown in Figure 4. Oxygen is made available for the reduction reaction by utilizing the oxygen excreted by the macrophyte roots within the cathode zone. Research has shown that with such incorporation, the wetland plant improves the cathode potential of the CW-MFC for optimum energy production. In an experiment conducted by Liu et al. [48], they compared CW-MFC planted with Ipomoea aquatica and unplanted CWMFC systems. It was evident from their study that the plants' presence can boost the system's electricity production by $142 \%$ [48]. They attained a maximum power density $\left(\mathrm{P}_{\mathrm{D}}\right)$ of $12.42 \mathrm{~mW} \cdot \mathrm{m}^{-2}$ generated from the system incorporated with I. aquatica, which was 142 percent greater than the $5.13 \mathrm{~mW} \cdot \mathrm{m}^{-2}$ generated from the system without aquatic macrophytes [48]. It was also observed by Saba et al. [55] that Ipomoea aquatica in CWMFC improved power generation from 0.191 to $0.302 \mathrm{~W} \cdot \mathrm{m}^{-3}$ by improving the cathode potential from $0.522 \mathrm{~V}$ to $0.603 \mathrm{~V}$ as a result of the oxygen availability by the plant root $[35,54]$. This result agrees with earlier experimentation from Shen et al. [44], where, to ascertain the contribution of Hydrilla verticillata in a CWMFC with regards to DO fixation, they observed that the DO of the planted system was 9 times higher than the unplanted. Further studies by Liu et al. [40] also assessed the DO concentration of four CWMFCs: unplanted CWMFC, and three CWMFCs planted with Canna indica, Acorus calamus, and Ipomoea aquatica. The DO concentration of the unplanted was remarkably lower $(1.95 \mathrm{mg} / \mathrm{L})$ than that of the planted. However, among the planted, the effluent of CWMFC planted with Canna indica demonstrated the highest $\mathrm{DO}$ concentration $(3.31 \mathrm{mg} / \mathrm{L})$, which indirectly led to higher bioelectricity production than the unplanted.

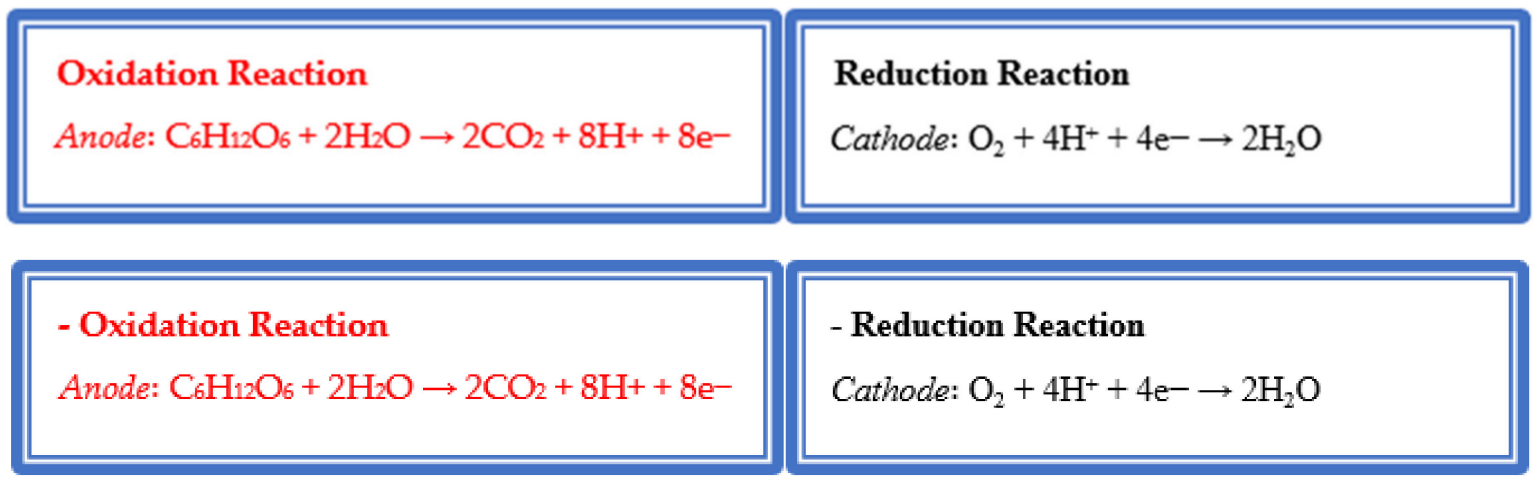

Figure 3. Oxidation and reduction reaction in their respective chambers.

Similarly, Di et al. [42] also assessed the influence of plant radial oxygen loss (ROL) in CWMFC in the removal of nitrobenzene from an aqueous solution. They compared three macrophyte species: Scirpus validus, Typha orientalis, and Iris pseudacorus, with unplanted CWMFC. Generally, their results demonstrated that the planted CWMFC were more efficient in power production and nitrobenzene removal than unplanted. However, relatively, Scirpus validus attained the highest power density $19.5 \mathrm{~mW} / \mathrm{m}^{2}$ due to its high DO production of $2.57 \pm 0.17 \mathrm{mg} / \mathrm{L}$ and root biomass of $16.42 \pm 0.18 \mathrm{~g} \cdot \mathrm{m}^{-2}$. In CWMFC, because of root oxygen exudation, aquatic plants play a crucial role in achieving a high oxidation-reduction potential between the two regions. In comparing the contribution of macrophytes in the creation of redox conditions necessary for power production, Doherty 
et al. [33] in their experiment, also reported that the presence of macrophytes had a more significant impact on redox conditions by creating a redox gradient that was 20 percent greater than that of the unplanted. Likewise, in a study conducted by Corbella et al. [56], the macrophytes' overall influence on redox conditions within the wetlands was analyzed by contrasting the planted and unplanted wetlands wrought under a continuous flow regime. Their results proved that plants increased the redox gradient with a subsequent energy production of $16 \mathrm{~mW} / \mathrm{m}^{2}$ higher than the unplanted. Similarly, Oon et al. [54], in their study to assess the role of macrophytes in an up-flow CWMFC by comparing planted with unplanted systems, established that DO at the cathodic region for planted systems was higher with a high reduction potential, compared to unplanted, making the planted system perform better than the control (unplanted) in their electrical output. The main transport mechanisms of oxygen in macrophyte CWMFC is by the air pressure gradient from the atmosphere and mainly via diffusion from the aerenchyma cells of roots during plant photosynthesis $[39,40,57]$. The oxygen secreted from the root aerenchyma cells creates a micro-oxidizing environment in the rhizosphere; hence, the redox potential of the system is greatly influenced $[58,59]$

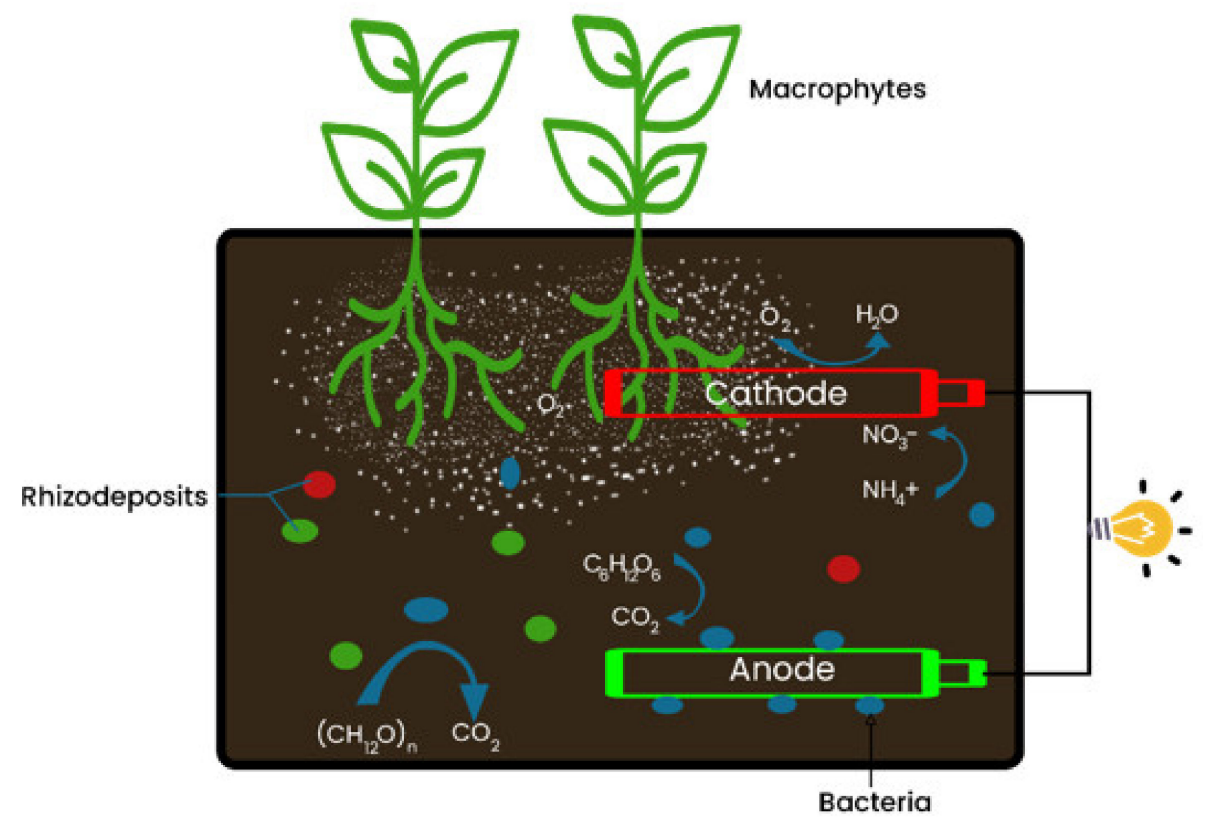

Figure 4. Macrophyte roots secrete $\mathrm{O}_{2}$ and $\left(\mathrm{CH}_{2} \mathrm{O}\right)_{n}$.

However, aside from plant root oxygenation, the secretion of exudates also plays a crucial role in bioelectricity production. Root exudates secreted from wetland plants are organic matter, and electroactive bacteria that form naturally within the anode region oxidize the exudates, producing electrons for the production of bioelectricity. Hence, macrophyte species with such propensity will have a great influence on the system's electrical output [59]. Guadarrama-Perez et al. [60] investigated the effect of four different native species-Aglaonema commutatum, Epipremnum aureum, Dranacaena braunni, and Philodendron cordatum - as the only endogenous substrate from their root exudate and the effect on bioelectricity production. Philodendron cordatum attained the highest power density of $12.5 \mathrm{~mW} \cdot \mathrm{m}^{-2}$ with a $20.6 \mathrm{mg} / \mathrm{L}$ maximum production of root exudates. Therefore, at an optimal condition for root exudate release, the CWMFC performance in terms of bioelectricity was observed to be higher. Different species based on their substrate type, transport, and exudate release will have a different effect as demonstrated by [60]. Zhou et al. [61] also investigated the effect of root exudates and oxygen release by four wetland plants, Canna indica, Cyperus alterniferlius, Acorus calamus, and A. donax, with unplanted CWMFC on power production. The $A$ donax macrophyte species attained the highest maximum power density of $12.82 \mathrm{~mW} \cdot \mathrm{m}^{-2}$ compared to the unplanted and the remaining 
species. From their results, they concluded that the relatively high rate of root exudation and oxygen release by aerenchyma was generally responsible for the high electrical output in A. donax. It is evident that wetland plants in CWMFC play a crucial role in power production. It is, therefore, highly imperative that the incorporation of macrophytes in CWMFC should be considered to ensure optimal power production. However, in the selection of such species, ROL and exudate production based on the photosynthetic process of the plant should be well considered. Further details on different types of macrophytes with their contribution to electricity generation are itemized in Table 1 [54].

\section{Role of Macrophyte in CW-MFC Contaminant Removal}

In many wastewater effluents, high COD levels, nutrients such as ammonium-nitrogen, nitrate-nitrogen, and phosphorus, and heavy metals are common pollutants. CWMFC as an eco-friendly technology can remove, transform, and immobilize these and many other wide ranges of contaminants [62]. The efficacy of CWMFC in wastewater treatment, however, depends on multifaced interacting processes that can be narrowly divided into three major categories-physical, chemical, and biological-as shown in Figure 5 below $[21,35,54,62]$.

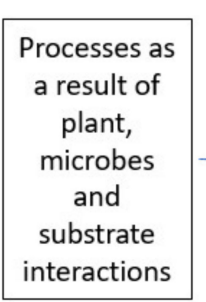

Processes as

plant,

and

interactions
CW-MFC wastewater treatment

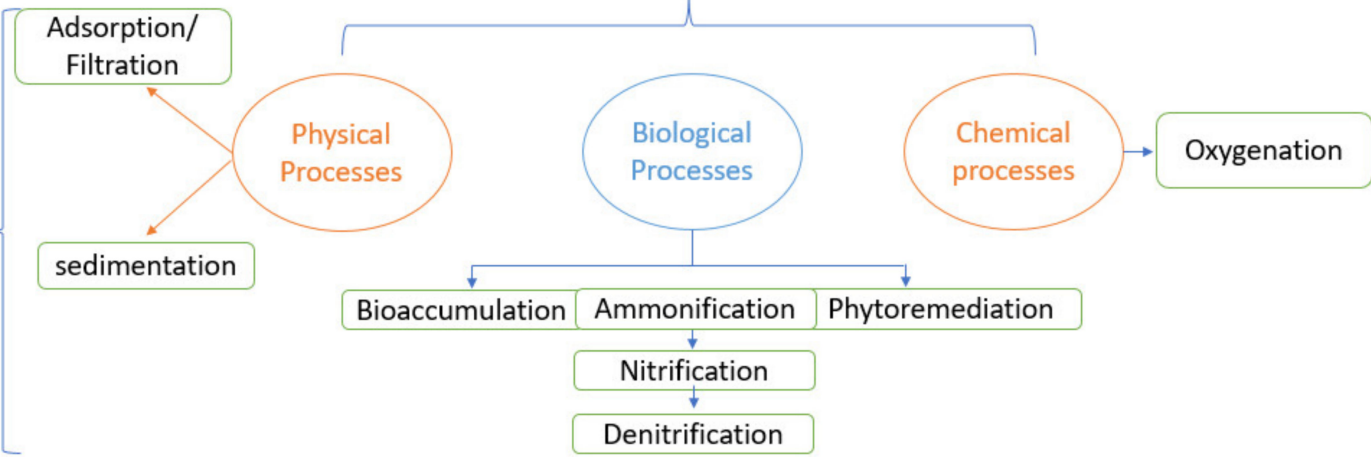

Figure 5. Interacting processes involved in contaminant removal.

The macrophyte component plays a versatile role in all of these processes to ensure the effective removal of wastewater contaminants. For example, in the bioaccumulation and phytoremediation process, aquatic plants have an important role in the absorption, assimilation, and storage of nutrients in their biomass, either directly or indirectly. They sequester soluble inorganic nutrients as a means of building their biomass $[21,24,62,63]$. Since these nutrients are necessary for their growth, the amount of nutrients from wastewater effluent can be maximized by choosing wetland plants with a high capacity for inorganic absorption and their subsequent conversion to organic plant biomass [57]. In addition, besides the release of oxygen (oxygenation) from plant roots to maintain a redox condition necessary to facilitate nitrification by aerobic microbes, the root system of submerged and emergent aquatic macrophytes releases exudates through a process called "rhizodeposition" $[18,25,33,64]$. These rhizodeposits act as an energy source for denitrifiers for the denitrification processes for the effective removal of nitrate in wastewater $[18,64,65]$. Organic rhizodeposits range from low molecular weight exudates to full roots used as energy sources for microorganisms in the CWMFC [17,62]. In a study conducted by Wen et al. [64] to assess the influence of macrophytes in ammonium nitrogen $\left(\mathrm{NH}_{4}{ }^{+}-\mathrm{N}\right)$, nitrate, and total nitrogen removal, they used Canna indica, a typical wetland plant, and their results showed that the planted CW-MFC was 38\% higher in removal efficiency than unplanted CW-MFC. This was mainly because the wetland plant enhanced the nitrification process. In a similar study, comparing planted CWMFC with unplanted CWMFC to investigate the role of plants (Canna indica) in the treatment of antibiotics and $\mathrm{NH}_{4}{ }^{+}-\mathrm{N}$, the presence of plants 
was observed to have accelerated the accumulation of sulfamethoxazole, tetracycline, and $\mathrm{NH}_{4}{ }^{+}-\mathrm{N}$ [59]. In addition to their inimitable role as bio accumulators, wetland plants also play an essential filtering and adsorption role by reducing wastewater's velocity and allowing finer particles to adhere to plants' biofilm surfaces. It is undoubtedly proven that the wetland plant species significantly affect pollutant removal in CWMFC $[17,62-64]$. In a study conducted by Liu et al. [48] to enhance the efficiency of CWMFC using plant photosynthate, the root exudates of Ipomoea aquatica were utilized as a part of the fuel in photosynthetic MFC to enhance denitrification [48]. Phragmites australis had better removal of $\mathrm{NH}_{4}-\mathrm{N}$ than Iris pseudacorus and was able to enhance the rhizosphere's nitrification process due to the more robust radial oxygen loss (ROL). A recent study by Oon et al. [54] using Elodea nutallii CWMFC operated under artificial aeration attained 98\% COD removal efficiency. In another recently conducted experiment in South Africa by Oodally et al. [66], to examine the contribution of macrophytes used in CWMFC, they compared three indigenous South African species: Phragmites australis, Cyperus prolifer, and Wachendorfia thyrsiflora with an unplanted system as control. They obtained a COD removal efficiency of $97 \pm$ $1 \%$ for Cyperus prolifer, which was higher than P. australis, Wachendorfia hyrsiflora, and the unplanted with $94 \pm 1 \%, 94 \pm 1 \%$, and $90 \pm 2 \%$ removal efficiencies, respectively. The Cyperus prolifer species attained a higher orthophosphate removal efficiency $(98 \pm 0 \%)$ than the control experiment (72 $\pm 7 \%$ ), Wachendorfia thyrsiflora (58 $\pm 6 \%$ ), and Phragmites australis $(81 \pm 4 \%)$. Comparatively, Cyperus prolifer was noticed to be the most suitable indigenous wetland plant for electricity production and COD, ammonia, and phosphate removal among the three species [66]. These results also justify Greenway's [62] assertion that different macrophyte species differ in their removal efficiency, hence the need for a proper investigation in selecting macrophyte species to be incorporated into the CWMFC system. Furthermore, studies on plant effects of nitrogen, phosphorus, and heavy metal removal are scanty, compared to the COD removal efficiency. Although generally proven under constructed wetlands (CW), extensive studies are required regarding CWMFC [63]. This study may help optimize the integration of the plant component in CWMFCs and boost the development of CWMFCs for practical use (see Table 1).

Table 1. COD removal efficiency and power density between different macrophytes based on earlier studies.

\begin{tabular}{|c|c|c|c|c|c|}
\hline Macrophyte & $\begin{array}{l}\text { Initial COD } \\
(\mathrm{mg} / \mathrm{L})\end{array}$ & $\begin{array}{c}\text { COD Removal } \\
(\%)\end{array}$ & HRT (hr) & Max. Power & Author \\
\hline Canna indica & 1500 & 74.9 & 96 & $15.7 \mathrm{~mW} \cdot \mathrm{m}^{-2}$ & {$[16]$} \\
\hline Phragmites australis & 1058 & 76.5 & N. A & $9.4 \mathrm{~mW} \cdot \mathrm{m}^{-2}$ & {$[67]$} \\
\hline Ipomoea aquatica & 180 & 86 & 72 & $0.302 \mathrm{~W} \cdot \mathrm{m}^{-3}$ & {$[34]$} \\
\hline Phragmites australis & 250 & 80-100 & N. A & $0.15 \mathrm{~mW} \cdot \mathrm{m}^{-2}$ & [68] \\
\hline Ipomoea aquatica & $193-205$ & 94.8 & 48 & $12.42 \mathrm{~mW} \cdot \mathrm{m}^{-2}$ & {$[48]$} \\
\hline Ipomoea aquatica & 300 & 72.5 & 72 & $0.852 \mathrm{~W} \cdot \mathrm{m}^{-3}$ & [69] \\
\hline Phragmites australis & $411-854$ & 64 & N. A & $0.268 \mathrm{~W} \cdot \mathrm{m}^{-3}$ & {$[32]$} \\
\hline Typha latifolia & 314.8 & 100 & N. A & $6.12 \mathrm{~mW} \cdot \mathrm{m}^{-2}$ & {$[70]$} \\
\hline Phragmites australis & 583 & 64 & N. A & $0.276 \mathrm{~W} \cdot \mathrm{m}^{-3}$ & {$[33]$} \\
\hline Taifa latifolia & 624 & 99 & 24 & $93 \mathrm{~mW} \cdot \mathrm{m}^{-3}$ & {$[71]$} \\
\hline Phragmite australis & 323 & 60.6 & 62.4 & $131 \mathrm{~mW} \cdot \mathrm{m}^{-2}$ & {$[72]$} \\
\hline Elodea nuttallii & 643 & 97-98 & 24 & $184.75 \mathrm{~mW} \cdot \mathrm{m}^{-3}$ & {$[54]$} \\
\hline Canna indica & - & 78.71 & 72 & $31.04 \mathrm{~mW} \cdot \mathrm{m}^{-3}$ & {$[73]$} \\
\hline Phragmites australis & 200 & 90.45 & 48 & $0.20 \mathrm{~W} \cdot \mathrm{m}^{-3}$ & [74] \\
\hline Phragmites australis & - & 82 & 72 & $3714 \mathrm{~mW} \cdot \mathrm{m}^{-2}$ & [75] \\
\hline
\end{tabular}




\section{Future Perspective}

In a CWMFC configuration, the appropriate selection of macrophytes is crucial for the system's success. The macrophyte component is one of the most conspicuous and versatile parts of the CWMFC bio-electrochemical system. The types of wetland plants installed in CWMFCs have some unique properties that make them play such an essential role in the contaminant removal processes and bioelectricity generation $[44-47,66]$. Therefore, a thorough selection of the type of macrophyte to be used is hugely imperative to the system's success. This decision can either enhance or retard CWMFC's efficiency significantly. Hence, an appropriate selection of wetland plants must be based on some unique characteristics, such as those outlined in Table 2.

Table 2. Characteristics of macrophytes and their relevance in CWMFC.

Macrophyte Properties
rapid growth and high biomass production

rapid growth and high biomass production

good natural adaptation to the local climate

good root development

High oxygen transfer capacity

nutrient absorption capacity

adaptation and ease of propagation

Good Rhizodeposition; release of carbon sources as rhizodeposits from plant roots.

\section{Relevance in CWMFC}

For winter insulation in cold and temperate regions, and particularly for the removal of nutrients by harvesting, as nutrients are absorbed by macrophytes to build their biomass [47]. In addition, according to Yang et al. [76], species with high biomass production in CWMFC enhance the cell voltage and reduce the internal resistance of the system, which often results in higher bioenergy production.

Native species should be best preferred. According to Sierra et al. [25], CWMFC plants are selected based on the region's most common aquatic plants. Oodally et al. [66], also concluded that native species are best preferred due to their local climate adaptability. In their experimentation, the most common aquatic plants in the region showed improved performance in CWMFC than exotic species.

To provide a substrate for attached bacteria and oxygenation [46,47]. Additionally, the root development or maturity of the wetland plant affects oxygen release. In a sediment microbial fuel cell (SMFC) with wetland plant experiments conducted by Chen et al. [58], their investigation has shown that young roots can excrete more oxygen than mature or aging species. Similarly, Colares et al. [41] also observed that plant species with good root development produced better oxygen, which presented the highest voltage value, compared to plants with smaller poor root systems. In addition, Moqsud et al. [77] operated a series of 6-CWMFC using Oriza sativa species. In their experimentation, they observed a reduction in power production as plants attained maturation. This was mainly because the maturation of the plant affected both oxygen release and exudate production. This signifies that the maturity of the root and its development is an essential factor in wetland plant selection [58].

Oxygen transfer capacity from the roots creates an aerobic environment. Due to the great diversity of flora, different species have different radial oxygen loss (ROL) [25].

High nutrient absorption capacity helps in the effective removal of contaminants from the system. Species with high NAC use absorbed nutrients as a resource for their metabolism and growth $[48,62]$.

The ease in obtaining seedlings, seeds, or vegetative propagules must be well considered to ensure system sustainability.

Rhizodeposition supports the growth and activities of microorganisms associated with bioelectricity production [78].

The photosynthetic activity of plants is categorized into three phases: $\mathrm{C} 3, \mathrm{C} 4$, and CAM. In terms of oxygen production and $\mathrm{CO}_{2}$ fixation, plants in each category have different photosynthetic pathways. Plants in the group of $\mathrm{C} 4$ are those with more advanced photosynthetic activity than plants in the C3 and CAM groups. Consequently, because they have a higher conversion rate of solar energy into bioelectricity, it is suggested to integrate C4 plants [18].

These factors should be primarily considered in the appropriate selection of macrophytes for CWMFC. Nevertheless, owing to the wide variety of aquatic flora, further 
investigation is needed to evaluate and select plant species with potential for CWMFC for simultaneous wastewater regeneration and bioelectricity production [79].

Macrophytes, particularly emergent plants, can cause substantial water loss in CWMFC through evapotranspiration. As the volume of wastewater flowing through the system decreases due to water loss, the treatment efficiency in CWMFCs could be affected significantly when the evapotranspiration rate exceeds $2.5 \mathrm{~mm} / \mathrm{d}[54,80]$. In addition, in the absence of light, plant cells and microorganism respiration consume $\mathrm{O}_{2}$. Hence, the DO level in the reactor will be reduced as the $\mathrm{DO}$ consumption rate exceeds production. The plant's photosynthesis and respiration alters the reactor's oxygen dynamics, ultimately leading to voltage fluctuations [22]. Therefore, macrophyte species that can help overcome these major setbacks are highly recommended.

\section{Conclusions}

From all previous and recent studies on the plant component of the CWMFC, there is no doubt that macrophytes have a significant effect on the performance of CWMFC for wastewater treatment and electricity generation. However, most of the studies conducted to assess the macrophytes' impact on treatment efficiency focused on COD removal, with less focus on nitrate, phosphorus, and heavy metal removal through the selection of appropriate macrophytes. Previous studies also focused on general macrophyte performance on treatment efficiency and power generation performance without comparing different species performance and plant hybrid integration of CW-MFC performance. This comparison and analysis will help in recommending the right wetland plant for the technology based on plant performance to filter contaminants, absorb heavy metals, excrete more dissolved oxygen needed to increase the system's redox potential, and aid in the removal of other pollutants. More macrophyte species must be explored to compare different species' performance on the system. Studies must also be conducted on the pollutant effect on the plant component of CWMFC, i.e., ascertaining the phytotoxicity caused by contaminants.

Author Contributions: Conceptualization, K.L., J.Q. and N.M.; methodology, N.M. and D.A.K.; software, V.E.S.; investigation, L.C.; resources, J.Q. and Y.Y.; writing-original draft preparation, K.L., P.S.A., and Y.D.; writing-review and editing, N.M., A.M.-n.S. and F.Z.; visualization, V.E.S.; supervision, K.L. and N.M.; funding acquisition, Y.Y. All authors have read and agreed to the published version of the manuscript.

Funding: This research was funded by National Natural Science Foundation of China, grant number 51878316; 52070087 and The APC was funded by 51878316; 52070087.

Institutional Review Board Statement: Not applicable.

Informed Consent Statement: Not applicable.

Data Availability Statement: Not applicable.

Conflicts of Interest: The authors declare no conflict of interest. The funders had no role in the design of the study; in the collection, analyses, or interpretation of data; in the writing of the manuscript, or in the decision to publish the results.

\section{References}

1. Singh, H.M.; Pathak, A.K.; Chopra, K.; Tyagi, V.V.; Anand, S.; Kothari, R. Microbial fuel cells: A sustainable solution for bioelectricity generation and wastewater treatment. Biofuels 2019, 10, 11-31. [CrossRef]

2. Glover, H.; Guz, E.; Hanewall, C.; Hollander, A.; Kocian, A. Alternative Financing of Water and Wastewater Infrastructure in Rural Communities; United States Department of Agriculture, Rural Development: Washington, DC, USA; Maxwell School of Syracuse University: Syracuse, NY, USA, 2005.

3. Liu, H.; Ramnarayanan, R.; Logan, B.E. Production of Electricity during Wastewater Treatment Using a Single Chamber Microbial Fuel Cell. Environ. Sci. Technol. 2004, 38, 2281-2285. [CrossRef]

4. Gude, V.G. Energy and water autarky of wastewater treatment and power generation systems. Renew. Sustain. Energy Rev. 2015, 45, 52-68. [CrossRef]

5. Virdis, B.; Freguia, S.; Rozendal, R.A.; Rabaey, K.; Yuan, Z.; Keller, J. Microbial Fuel Cells. In Treatise on Water Science; Elsevier: Amsterdam, The Netherlands, 2011; Volume 4, pp. 641-665. 
6. Das, D. Microbial Fuel Cell - A Bioelectrochemical System that Converts Waste to Watts; Springer: Berlin/Heidelberg, Germany, 2018; p. 20. ISBN 978-3-319-66792-8.

7. Potter, M.C. Electrical effects accompanying the decomposition of organic compounds. Proc. R. Soc. B Biol. Sci. 1911, 84, 260-276. [CrossRef]

8. Logan, B.E. Microbial Fuel Cells; John Wiley \& Sons: Hoboken, NJ, USA, 2008.

9. Vymazal, J. Constructed Wetlands for Wastewater Treatment. Water 2010, 2, 530-549. [CrossRef]

10. Yang, E.; Chae, K.-J.; Choi, M.-J.; He, Z.; Kim, I.S. Critical review of bioelectrochemical systems integrated with membrane-based technologies for desalination, energy self-sufficiency, and high-efficiency water and wastewater treatment. Desalination 2019, 452, 40-67. [CrossRef]

11. Vidal, C.C. Constructed Wetland Microbial Fuel Cells: Electricity Generation, Treatment Efficiency Improvement, COD Bioindication and Clogging Assessment. Ph.D. Thesis, Universitat Politecnica de Catalunya, Barcelona, Spain, 2017.

12. Wu, H.; Zhang, J.; Ngo, H.H.; Guo, W.; Hu, Z.; Liang, S.; Fan, J.; Liu, H. A review on the sustainability of constructed wetlands for wastewater treatment: Design and operation. Bioresour. Technol. 2015, 175, 594-601. [CrossRef]

13. Scholz, M.; Lee, B. Constructed wetlands: A review. Int. J. Environ. Stud. 2005, 62, 421-447. [CrossRef]

14. Yadav, A.K.; Srivastava, P.; Kumar, N.; Abbassi, R.; Mishra, B.K. Constructed Wetland-Microbial Fuel Cell: An Emerging Integrated Technology for Potential Industrial Wastewater Treatment and Bio-Electricity Generation. Constr. Wetl. Ind. Wastewater Treat. 2018, 493-510. [CrossRef]

15. Wang, Y.; Zhao, Y.; Xu, L.; Wang, W.; Doherty, L.; Tang, C.; Ren, B.; Zhao, J. Constructed wetland integrated microbial fuel cell system: Looking back, moving forward. Water Sci. Technol. 2017, 76, 471-477. [CrossRef] [PubMed]

16. Yadav, A.K.; Dash, P.; Mohanty, A.; Abbassi, R.; Mishra, B.K. Performance assessment of innovative constructed wetland-microbial fuel cell for electricity production and dye removal. Ecol. Eng. 2012, 47, 126-131. [CrossRef]

17. Brix, H.; Schierup, H.H. The Use of Aquatic Macrophytes in Water-Pollution Control. Ambio 1989, 28, $100-107$.

18. Guadarrama-Pérez, O.; Gutiérrez-Macías, T.; García-Sánchez, L.; Guadarrama-Pérez, V.H.; Estrada-Arriaga, E.B. Recent advances in constructed wetland-microbial fuel cells for simultaneous bioelectricity production and wastewater treatment: A review. Int. J. Energy Res. 2019, 43, 5106-5127. [CrossRef]

19. Brisson, J.; Chazarenc, F. Maximizing pollutant removal in constructed wetlands: Should we pay more attention to macrophyte species selection? Sci. Total Environ. 2009, 407, 3923-3930. [CrossRef]

20. Srivastava, P.; Abbassi, R.; Yadav, A.K.; Garaniya, V.; Asadnia, M. A review on the contribution of electron flow in electroactive wetlands: Electricity generation and enhanced wastewater treatment. Chemosphere 2020, 254, 126926. [CrossRef]

21. Jingyu, H.; Miwornunyuie, N.; Ewusi-Mensah, D.; Koomson, D. Assessing the factors influencing the performance of constructed wetland-microbial fuel cell integration. Water Sci. Technol. 2020, 81, 631-643. [CrossRef] [PubMed]

22. Doherty, L.; Zhao, Y.; Zhao, X.; Hu, Y.; Hao, X.; Xu, L.; Liu, R. A review of a recently emerged technology: Constructed wetland-microbial fuel cells. Water Res. 2015, 85, 38-45. [CrossRef]

23. Shi, Y.; Yang, X.; Ning, X.; Yang, Q. Research progress of microbial fuel cell and constructed wetland coupling system. IOP Conf. Ser. Earth Environ. Sci. 2018, 199, 052014. [CrossRef]

24. Srivastava, P.; Yadav, A.K.; Garaniya, V.; Abbassi, R. Constructed Wetland Coupled Microbial Fuel Cell Technology. In Microbial Electrochemical Technology; Elsevier: Amsterdam, The Netherlands, 2019; pp. 1021-1036.

25. Sierra, M.A.; Esteve Núñez, A.; Salas Rodriguez, J.J. Integrating Microbial Electrochemical Systems in Constructed Wetlands, a New Paradigm for Treating Wastewater in Small Communities. Ph.D. Thesis, Universidad de Alcalá, Madrid, Spain, 2017; pp. 100-165.

26. Yang, Y.; Zhao, Y.; Liu, R.; Morgan, D. Global development of various emerged substrates utilized in constructed wetlands. Bioresour. Technol. 2018, 261, 441-452. [CrossRef]

27. Yan, D.; Song, X.; Weng, B.; Yu, Z.; Bi, W.; Wang, J. Bioelectricity generation from air-cathode microbial fuel cell connected to constructed wetland. Water Sci. Technol. 2018, 78, 1990-1996. [CrossRef]

28. Fang, Z.; Cheng, S.; Wang, H.; Cao, X.; Li, X. Feasibility study of simultaneous azo dye decolorization and bioelectricity generation by microbial fuel cell-coupled constructed wetland: Substrate effects. RSC Adv. 2017, 7, 16542-16552. [CrossRef]

29. Srivastava, P.; Yadav, A.K.; Mishra, B.K. The effects of microbial fuel cell integration into constructed wetland on the performance of constructed wetland. Bioresour. Technol. 2015, 195, 223-230. [CrossRef]

30. Araneda, I.; Tapia, N.F.; Allende, K.L.; Vargas, I.T. Constructed Wetland-Microbial Fuel Cells for Sustainable Greywater Treatment. Water 2018, 10, 940. [CrossRef]

31. Kalathil, S.; Patil, S.A.; Pant, D. Microbial Fuel Cells: Electrode Materials; Elsevier Inc.: Amsterdam, The Netherlands, 2018.

32. Doherty, L.; Zhao, X.; Zhao, Y.; Wang, W. The effects of electrode spacing and flow direction on the performance of microbial fuel cell-constructed wetland. Ecol. Eng. 2015, 79, 8-14. [CrossRef]

33. Doherty, L.; Zhao, Y.; Zhao, X.; Wang, W. Nutrient and organics removal from swine slurry with simultaneous electricity generation in an alum sludge-based constructed wetland incorporating microbial fuel cell technology. Chem. Eng. J. 2015, 266, 74-81. [CrossRef]

34. Fang, Z.; Song, H.-L.; Cang, N.; Li, X.-N. Performance of microbial fuel cell coupled constructed wetland system for decolorization of azo dye and bioelectricity generation. Bioresour. Technol. 2013, 144, 165-171. [CrossRef] [PubMed] 
35. Stottmeister, U.; Wießner, A.; Kuschk, P.; Kappelmeyer, U.; Kästner, M.; Bederski, O.; Müller, R.; Moormann, H. Effects of plants and microorganisms in constructed wetlands for wastewater treatment. Biotechnol. Adv. 2003, 22, 93-117. [CrossRef]

36. Wang, L.; Li, Y.; Li, X.; Han, B. A labscale study on constructed wetland microbial fuel cell. Acta Sci. Circumstantiae 2017, 37, 3656-3663.

37. Zhai, X.; Piwpuan, N.; Arias, C.A.; Headley, T.; Brix, H. Can root exudates from emergent wetland plants fuel denitrification in subsurface flow constructed wetland systems? Ecol. Eng. 2013, 61, 555-563. [CrossRef]

38. Guang, L.; Koomson, D.A.; Jingyu, H.; Ewusi-Mensah, D.; Miwornunyuie, N.; Miwornunyuie, N. Performance of Exoelectrogenic Bacteria Used in Microbial Desalination Cell Technology. Int. J. Environ. Res. Public Health 2020, 17, 1121. [CrossRef]

39. ElZein, Z.; Abdou, A.; ElGawad, I.A. Constructed Wetlands as a Sustainable Wastewater Treatment Method in Communities. Procedia Environ. Sci. 2016, 34, 605-617. [CrossRef]

40. Liu, F.; Sun, L.; Wan, J.; Shen, L.; Yu, Y.; Hu, L.; Zhou, Y. Performance of different macrophytes in the decontamination of and electricity generation from swine wastewater via an integrated constructed wetland-microbial fuel cell process. J. Environ. Sci. 2020, 89, 252-263. [CrossRef] [PubMed]

41. Colares, G.S.; Dell'Osbel, N.; Barbosa, C.V.; Lutterbeck, C.; Oliveira, G.A.; Rodrigues, L.R.; Bergmann, C.P.; Lopez, D.R.; Rodriguez, A.L.; Vymazal, J.; et al. Floating treatment wetlands integrated with microbial fuel cell for the treatment of urban wastewaters and bioenergy generation. Sci. Total Environ. 2021, 766, 142474. [CrossRef]

42. Di, L.; Li, Y.; Nie, L.; Wang, S.; Kong, F. Influence of plant radial oxygen loss in constructed wetland combined with microbial fuel cell on nitrobenzene removal from aqueous solution. J. Hazard. Mater. 2020, 394, 122542. [CrossRef] [PubMed]

43. Alufasi, R.; Gere, J.; Chakauya, E.; Lebea, P.; Parawira, W.; Chingwaru, W. Mechanisms of pathogen removal by macrophytes in constructed wetlands. Environ. Technol. Rev. 2017, 6, 135-144. [CrossRef]

44. Shen, X.; Zhang, J.; Liu, D.; Hu, Z.; Liu, H. Enhance performance of microbial fuel cell coupled surface flow constructed wetland by using submerged plants and enclosed anodes. Chem. Eng. J. 2018, 351, 312-318. [CrossRef]

45. Wang, J.; Song, X.; Wang, Y.; Bai, J.; Bai, H.; Yan, D.; Cao, Y.; Li, Y.; Yu, Z.; Dong, G. Bioelectricity generation, contaminant removal and bacterial community distribution as affected by substrate material size and aquatic macrophyte in constructed wetland-microbial fuel cell. Bioresour. Technol. 2017, 245, 372-378. [CrossRef]

46. Wang, J.; Song, X.; Wang, Y.; Bai, J.; Li, M.; Dong, G.; Lin, F.; Lv, Y.; Yan, D. Bioenergy generation and rhizodegradation as affected by microbial community distribution in a coupled constructed wetland-microbial fuel cell system associated with three macrophytes. Sci. Total Environ. 2017, 607-608, 53-62. [CrossRef]

47. Vymazal, J. Plants used in constructed wetlands with horizontal subsurface flow: A review. Hydrobiologia 2011, 674, 133-156. [CrossRef]

48. Liu, S.; Song, H.; Li, X.; Yang, F. Power Generation Enhancement by Utilizing Plant Photosynthate in Microbial Fuel Cell Coupled Constructed Wetland System. Int. J. Photoenergy 2013, 2013, 172010. [CrossRef]

49. Gude, V.G. Microbial Fuel Cells for Wastewater Treatment and Energy Generation Wastewater treatment in microbial fuel cells e an overview. J. Clean. Prod. 2018, 122, 287-307. [CrossRef]

50. Clauwaert, P.; Rabaey, K.; Aelterman, P.; de Schamphelaire, L.; Pham, T.H.; Boeckx, P.; Boon, N.; Verstraete, W. Biological Denitrification in Microbial Fuel Cells. Environ. Sci. Technol. 2007, 41, 3354-3360. [CrossRef] [PubMed]

51. Jadhav, D.A.; Ghadge, A.N.; Mondal, D.; Ghangrekar, M.M. Comparison of oxygen and hypochlorite as cathodic electron acceptor in microbial fuel cells. Bioresour. Technol. 2014, 154, 330-335. [CrossRef]

52. Xu, L.; Zhao, Y.; Doherty, L.; Hu, Y.; Hao, X. The integrated processes for wastewater treatment based on the principle of microbial fuel cells: A review. Crit. Rev. Environ. Sci. Technol. 2016, 46, 60-91. [CrossRef]

53. Guo, L.; He, K.; Wu, S.; Sun, H.; Wang, Y.; Huang, X.; Dong, R. Optimization of high-rate TN removal in a novel constructed wetland integrated with microelectrolysis system treating high-strength digestate supernatant. J. Environ. Manag. 2016, 178, 42-51. [CrossRef]

54. Oon, Y.-L.; Ong, S.-A.; Ho, L.-N.; Wong, Y.-S.; Dahalan, F.A.; Lehl, H.; Thung, W.-E.; Nordin, N. Role of macrophyte and effect of supplementary aeration in up-flow constructed wetland-microbial fuel cell for simultaneous wastewater treatment and energy recovery. Bioresour. Technol. 2017, 224, 265-275. [CrossRef]

55. Saba, B.; Khan, M.; Christy, A.D.; Veno, B. Bioelectrochemistry Microbial phyto-power systems-A sustainable integration of phytoremediation and microbial fuel cells. Bioelectrochemistry 2019, 127, 1-11. [CrossRef]

56. Corbella, C.; Garfí, M.; Puigagut, J. Vertical redox profiles in treatment wetlands as function of hydraulic regime and macrophytes presence: Surveying the optimal scenario for microbial fuel cell implementation. Sci. Total Environ. 2014, 470-471, 754-758. [CrossRef]

57. Wang, Q.; Hu, Y.; Xie, H.; Yang, Z. Constructed Wetlands: A Review on the Role of Radial Oxygen Loss in the Rhizosphere by Macrophytes. Water 2018, 10, 678. [CrossRef]

58. Chen, Z.; Huang, Y.-C.; Liang, J.-H.; Zhao, F.; Zhu, Y.-G. A novel sediment microbial fuel cell with a biocathode in the rice rhizosphere. Bioresour. Technol. 2012, 108, 55-59. [CrossRef] [PubMed]

59. Wen, H.; Zhu, H.; Yan, B.; Xu, Y.; Shutes, B. Treatment of typical antibiotics in constructed wetlands integrated with microbial fuel cells: Roles of plant and circuit operation mode. Chemosphere 2020, 250, 126252. [CrossRef] [PubMed]

60. Guadarrama-Pérez, O.; Bahena-Rabadan, K.Y.; Dehesa-Carrasco, U.; Pérez, V.H.G.; Estrada-Arriaga, E.B. Bioelectricity production using shade macrophytes in constructed wetlands-microbial fuel cells. Environ. Technol. 2020, 1-12. [CrossRef] [PubMed] 
61. Zhou, Y.; Xu, D.; Xiao, E.; Xu, D.; Xu, P.; Zhang, X.; Zhou, Q.; He, F.; Wu, Z. Relationship between electrogenic performance and physiological change of four wetland plants in constructed wetland-microbial fuel cells during non-growing seasons. J. Environ. Sci. 2018, 70, 54-62. [CrossRef] [PubMed]

62. Greenway, M. The Role of Macrophytes in Nutrient Removal using Constructed Wetlands. Environ. Bioremediat. Technol. 2007, 331-351. [CrossRef]

63. Vymazal, J. Removal of nutrients in various types of constructed wetlands. Sci. Total Environ. 2007, 380, 48-65. [CrossRef]

64. Wen, H.; Zhu, H.; Yan, B.; Shutes, B.; Yu, X.; Cheng, R.; Chen, X.; Wang, X. Constructed wetlands integrated with microbial fuel cells for COD and nitrogen removal affected by plant and circuit operation mode. Environ. Sci. Pollut. Res. 2021, 28, 3008-3018. [CrossRef]

65. Chiranjeevi, P.; Yeruva, D.K.; Kumar, A.K.; Mohan, S.V.; Varjani, S. Plant-microbial fuel cell technology. Microb. Electrochem. Technol. 2019, 549-564. [CrossRef]

66. Oodally, A.; Gulamhussein, M.; Randall, D.G. Investigating the performance of constructed wetland microbial fuel cells using three indigenous South African wetland plants. J. Water Process Eng. 2019, 32, 100930. [CrossRef]

67. Zhao, Y.; Collum, S.; Phelan, M.; Goodbody, T.; Doherty, L.; Hu, Y. Preliminary investigation of constructed wetland incorporating microbial fuel cell: Batch and continuous flow trials. Chem. Eng. J. 2013, 229, 364-370. [CrossRef]

68. Villaseñor, J.; Capilla, P.; Rodrigo, M.A.; Cañizares, P.; Fernández, F. Operation of a horizontal subsurface flow constructed wetland-microbial fuel cell treating wastewater under different organic loading rates. Water Res. 2013, 47, 6731-6738. [CrossRef]

69. Fang, Z.; Song, H.-L.; Cang, N.; Li, X.-N. Electricity production from Azo dye wastewater using a microbial fuel cell coupled constructed wetland operating under different operating conditions. Biosens. Bioelectron. 2015, 68, 135-141. [CrossRef] [PubMed]

70. Oon, Y.-L.; Ong, S.-A.; Ho, L.-N.; Wong, Y.-S.; Lehl, H.; Thung, W.-E. Hybrid system up-flow constructed wetland integrated with microbial fuel cell for simultaneous wastewater treatment and electricity generation. Bioresour. Technol. 2015, 186, 270-275. [CrossRef]

71. Oon, Y.-L.; Ong, S.-A.; Ho, L.-N.; Wong, Y.-S.; Dahalan, F.A.; Lehl, H.; Thung, W.-E. Synergistic effect of up-flow constructed wetland and microbial fuel cell for simultaneous wastewater treatment and energy recovery. Bioresour. Technol. 2016, 203, 190-197. [CrossRef] [PubMed]

72. Corbella, C.; Garfí, M.; Puigagut, J. Long-term assessment of best cathode position to maximise microbial fuel cell performance in horizontal subsurface flow constructed wetlands. Sci. Total Environ. 2016, 563-564, 448-455. [CrossRef] [PubMed]

73. Srivastava, P.; Dwivedi, S.; Kumar, N.; Abbassi, R.; Garaniya, V.; Yadav, A.K. Performance assessment of aeration and radial oxygen loss assisted cathode based integrated constructed wetland-microbial fuel cell systems. Bioresour. Technol. 2017, 244, 1178-1182. [CrossRef]

74. Song, H.; Zhang, S.; Long, X.; Yang, X.; Li, H.; Xiang, W. Optimization of Bioelectricity Generation in Constructed WetlandCoupled Microbial Fuel cell Systems. Water 2017, 9, 185. [CrossRef]

75. Xu, F.; Cao, F.-Q.; Kong, Q.; Zhou, L.-L.; Yuan, Q.; Zhu, Y.-J.; Wang, Q.; Du, Y.-D.; Wang, Z.-D. Electricity production and evolution of microbial community in the constructed wetland-microbial fuel cell. Chem. Eng. J. 2018, 339, 479-486. [CrossRef]

76. Yang, Y.; Zhao, Y.; Tang, C.; Liu, R.; Chen, T. Dual role of macrophytes in constructed wetland-microbial fuel cells using pyrrhotite as cathode material: A comparative assessment. Chemosphere 2021, 263, 128354. [CrossRef]

77. Moqsud, M.; Yoshitake, J.; Bushra, Q.; Hyodo, M.; Omine, K.; Strik, D. Compost in plant microbial fuel cell for bioelectricity generation. Waste Manag. 2015, 36, 63-69. [CrossRef]

78. Saz, Ç.; Türe, C.; Türker, O.C.; Yakar, A. Effect of vegetation type on treatment performance and bioelectric production of constructed wetland modules combined with microbial fuel cell (CW-MFC) treating synthetic wastewater. Environ. Sci. Pollut. Res. 2018, 25, 8777-8792. [CrossRef]

79. Vogelmann, S.; Awe, G.O.; Prevedello, J. Selection of plant species used in wastewater treatment. Water Air Soil Pollut. 2017, 9-18. Available online: https:/ / www.researchgate.net/publication/313874379 (accessed on 18 July 2021).

80. Białowiec, A.; Albuquerque, A.; Randerson, P.F. The influence of evapotranspiration on vertical flow subsurface constructed wetland performance. Ecol. Eng. 2014, 67, 89-94. [CrossRef] 